Doi: HTTPS://DOI.ORG/10.23910/IJBSM/2017.8.1.1750a

\title{
Effect of Plant Growth Regulators on Tiller Dynamics and Yield of Sugarcane (Saccharum officinarum L.)
}

\author{
Subhashisa Praharaj ${ }^{1 *}$, Dheer Singh ${ }^{1}$, S. K. Guru² and Bolta Ram Meena ${ }^{1}$
}

${ }^{1}$ Dept. of Agronomy, ${ }^{2}$ Dept. of Plant Physiology, G. B. Pant University of Agriculture and Technology, Pantnagar, Uttarakhand (263 145), India

\section{Corresponding Author}

Subhashisa Praharaj

e-mail:praharaj93@gmail.com

\author{
Article History \\ Manuscript No. AR1750a \\ Received in $13^{\text {th }}$ Dec, 2016 \\ Received in revised form $4^{\text {th }}$ Feb, 2017 \\ Accepted in final form $7^{\text {th }}$ Feb, 2017
}

\begin{abstract}
A field experiment was conducted during spring 2015-16 at Pantnagar, Uttarakhand with the objective to study the effect of ethephon and gibberellic acid on tiler dynamics, millble cane production and yield of sugarcane. Ten treatments i.e. conventional planting $\left(T_{1}\right)$, overnight soaking of setts in water $\left(T_{2}\right)$, overnight soaking of setts in 50 ppm ethephon $\left(T_{3}\right)$, overnight soaking of setts in 100 ppm ethephon ( $\left.T_{4}\right)$, $\mathrm{T}_{1}+$ foliar application of $\mathrm{GA}_{3} @ 35 \mathrm{ppm}$ at 90, 120 and $150 \mathrm{DAP}\left(\mathrm{T}_{5}\right), \mathrm{T}_{2}+$ foliar application of $\mathrm{GA}_{3} @ 35 \mathrm{ppm}$ at 90,120 and $150 \mathrm{DAP}\left(\mathrm{T}_{6}\right), \mathrm{T}_{3}+\mathrm{foliar}$ application of $\mathrm{GA}_{3} @ 35$ ppm at 90, 120 and $150 \mathrm{DAP}\left(\mathrm{T}_{7}\right), \mathrm{T}_{4}$ +foliar application of $\mathrm{GA}_{3} @ 35$ ppm at 90,120 and $150 \mathrm{DAP}\left(\mathrm{T}_{8}\right)$, soaking of setts for six hours in 50 ppm ethephon $\left(T_{9}\right)$ and six hour soaking of setts in 100 ppm ethephon $\left(T_{10}\right)$ were laid down in a randomized block design with 3 replication. Soil of the experiment plot was silty clay loam having high organic carbon (1.04\%), high available phosphorus $\left(32.5 \mathrm{~kg} \mathrm{ha}^{-1}\right)$, medium in available potassium $\left(256.2 \mathrm{~kg} \mathrm{ha}^{-1}\right)$ and low in available nitrogen $\left(233.4 \mathrm{~kg} \mathrm{ha}^{-1}\right)$. The soil was neutral in $\mathrm{pH}(7.2)$. The treatment in which setts were planted after overnight soaking with $100 \mathrm{ppm}$ ethephon followed by foliar application of gibberellic acid @ 35 ppm at 90, 120 and 150 DAP was found to improve tiller production, number of millable canes and yield of the crop.
\end{abstract}

Keywords: Sugarcane, tiller dynamics, ethephon, gibberellic acid, yield

\section{Introduction}

Sugarcane (Saccharum officinarum L.) is one of the important commercial crop of India and sustains second largest agro-industry i.e. sugar industry, next to textile industry (Anonymous, 2013). Indian sugar industry contributes significantly to the economy of India and to the socio-economic development of the rural population in the country, as more than 6 million farmers are engaged in its cultivation. Besides half a million skilled and semiskilled workers, mostly from rural area are also engaged in sugar Industry (Anonymous, 2011).

Sugarcane is vegetatively propagated through stem cuttings or setts. A sugarcane clump comprises of several cane stalks arising from subsurface sprouting of the underground buds in the form of tillers which develop into millable canes. These millable canes serve as sink for sucrose accumulation (Kapur et al., 2011). Most of the tillers produced after 2-3 months usually die and hence don't contribute to cane yield. Hence for high cane productivity improvement in tiller production with less mortality holds due importance. Many factors such as weather condition during tillering, nature of genotype and hormonal concentration largely affects tiller production as well as senescence. Variation in content of hormones like IAA, GA, and ABA in live and senescing tiller has been reported (Vasanta et al., 2012). Relation between endogenous hormone concentration and tillering behavior has also been reported by Shrivastava and Misra (1996).

Hence exogenous application of plant growth regulators may be a useful option in improving tillering and reducing tiller mortality or senescence in sugarcane Diaz et al. (1995) reported a significant increase in stalk population of two poorly germinating sugarcane varieties, when setts were dipped in ethephon solution prior to planting. Increase in tiller population due to ethepon treatment was also reported by Millhollon and Legendre (1995). El-Lattief and Bekheet (2012) reported that foliar spray of $\mathrm{GA}_{3}$ in sugarcane improved the stalk population ha-1. In addition to this, PGRs like ethephon and gibberellic acid has immense potential to in improve productivity and sugar recovery in sugarcane (Li and Solomon, 2003; Jain et al., 2011; El Latieff and Bekheet, 2012). Keeping these facts in view a field experiment was conducted with an objective to improve tiller population and produce higher no. of millable canes, thus producing higher yield. 


\section{Materials and Methods}

A field experiment was conducted during spring 2015-2016 in the N.E. Borlaug Crop Research Centre of Govind Ballabh Pant University of Agriculture and Technology, Pantnagar, Uttarakhand, India. The soil of the experiment plot was silty clay loam, rich in organic carbon (1.04\%), high in available phosphorus (32.5 kg $\mathrm{P}_{2} \mathrm{O}_{5} \mathrm{ha}^{-1}$ ) and medium in available potassium (256.2 $\left.\mathrm{kg} \mathrm{K}_{2} \mathrm{O} \mathrm{ha}^{-1}\right)$. $\mathrm{pH}$ of the soil was 7.2. Ten treatments i.e. conventional planting $\left(T_{1}\right)$, overnight soaking of setts in water $\left(T_{2}\right)$, overnight soaking of setts in $50 \mathrm{ppm}$ ethephon $\left(T_{3}\right)$, overnight soaking of setts in 100 ppm ethephon $\left(\mathrm{T}_{4}\right), \mathrm{T}_{1}+$ foliar application of $\mathrm{GA}_{3} @ 35 \mathrm{ppm}$ at 90,120 and 150 $\operatorname{DAP}\left(\mathrm{T}_{5}\right), \mathrm{T}_{2}+$ foliar application of GA $@ 35$ ppm at 90, 120 and 150 DAP $\left(\mathrm{T}_{6}\right), \mathrm{T}_{3}$ +foliar application of $\mathrm{GA}_{3} @ 35$ ppm at 90,120 and 150 DAP $\left(\mathrm{T}_{7}\right), \mathrm{T}_{4}$ +foliar application of $\mathrm{GA}_{3} @ 35 \mathrm{ppm}$ at 90,120 and $150 \mathrm{DAP}\left(\mathrm{T}_{8}\right)$, soaking of setts for six hours in 50 ppm ethephon $\left(T_{9}\right)$ and six hour soaking of setts in 100 ppm ethephon $\left(\mathrm{T}_{10}\right)$ were laid down in a randomized block design with replications. Three budded sugarcane setts of variety Co pant-3220 were planted in flat bed method at a row to row spacing of $75 \mathrm{~cm}$. A dose of $120 \mathrm{~kg}$ nitrogen, $60 \mathrm{~kg} \mathrm{P}_{2} \mathrm{O}_{5}$ and $40 \mathrm{~kg} \mathrm{~K}_{2} \mathrm{O} \mathrm{ha}^{-1}$ was applied through urea (46\% N), single super phosphate $\left(16 \% \mathrm{P}_{2} \mathrm{O}_{5}\right)$ and muriate of potash $\left(60 \% \mathrm{~K}_{2} \mathrm{O}\right)$. Half dose of nitrogen was applied as basal in furrows at the time of planting and remaining was top dressed in two equal splits in the month of last week of May and third week of June. However, full dose of phosphorus and potassium was applied at the time of planting. To control weeds atrazine was sprayed @ 2 kg a.i. ha-1 two days after planting by tractor operated power sprayer. Before planting setts were either soaked with water or ethephon. For water soaking treatment, setts were soaked overnight in tubewell water. Setts were soaked in 50 and 100 ppm ethephon solution for two different duration i.e 6 hours and overnight. Ethephon treated setts were used for planting immediately after completion of soaking duration. Gibberellic acid was sprayed @ 35 ppm at 90, 120 and 150 DAP. In conventional planting setts were planted without any sett soaking treatment.

The no. of tillers (shoots) per net plot was counted at 90, 120, 150 and 180 DAP from all plots and the data was presented as no of shoots per hectare. For measuring shoot height, Five randomly selected shoots in each net plot were tagged. The height of all five shoots was measured from base of the stem to tip of the top most leaf with the help of meter scale at monthly interval starting from 90 days till 180 DAP. The average height of shoot was calculated on the basis of five shoots. The millable canes from each net plot were counted at the time of harvest and their number was calculated on hectare basis. The crop was harvested during February, 2016. The weight of millable canes from each net plot was recorded separately with the help of plateform balance and the cane yield ha-1 was computed on the basis of net plot area and expressed in $\mathrm{t} \mathrm{ha}^{-1}$.

The data obtained during the course of investigation were subjected to statistical analysis using analysis of variance technique prescribed for randomized block design, to test difference among treatments means by the 'F-test' (Gomez and Gomez, 1984).

\section{Results and Discussion}

Tiller dynamics in terms of number of tillers (shoots) and shoot height at different growth stages was taken. No. of millable cane at harvest was counted to know how many tillers have been converted into millable canes to contribute commercial cane sugar production.

\subsection{No. of tillers}

No. of tillers varied significantly at all the stages of crop growth under different treatments. At 90 DAP, highest tillering (114.99 '000 ha-1) was recorded in the treatment of overnight setts soaking in $100 \mathrm{ppm}$ ethephon $\left(\mathrm{T}_{4}\right)$ which was significantly higher over other treatments except treatment $T_{6}, T_{8}$ and $T_{10}$.

At 120 days stage, there was continuous increase in tiller number in all the treatment irrespective of the treatments. The highest tiller count 148.10 ('000 ha-1) was recorded in the treatment of overnight soaking in 100 ppm ethephon $\left(T_{4}\right)$ followed by $\mathrm{T}_{8}$ (overnight soaking with $100 \mathrm{ppm}$ ethephon $+\mathrm{GA}_{3}$ @ 35 ppm at 90, 120 and 150 DAP. Number of tillers were lowest i.e.118.49 ('000 ha-1) in conventional (without any treatment) (Table 1).

At 150 days stage, the highest tiller count was recorded in $\mathrm{T}_{4}$ (overnight soaking with 100 ppm ethephon) followed by $\mathrm{T}_{8}$ (overnight soaking with 100 ppm ethephon+GA $@ 35$ ppm at 90, 120 and 150 DAP), which were significantly higher over rest of the treatments. At 180 days stage, though there was some mortality in tillers in all the treatments irrespective of the treatments but the trend was the same and the highest tiller count was recorded in the treatment of overnight sett soaking in ethephon @ 100 ppm $\left(\mathrm{T}_{4}\right)$ followed by $\mathrm{T}_{8}$. It means number of tillers per unit area could not be improved due to $\mathrm{GA}_{3}$ application. These two treatments were at par with each other but were significantly higher over rest of the treatments. The increase in tillers was $24 \%$ higher in 100 ppm ethephon treated crop as compared to conventional (without treatment). It was evident from the observations that number of tillers were significantly higher under overnight sett soaking with 100 ppm ethephon as compared to lower concentration (50 ppm) as well as duration (6 hour) of ethephon soaking. Higher tiller production due to ethephon treatment has also been reported by many workers (Li and Solomon, 2003). Diaz et al. (1995) also reported a significant increase in stalk population of two poorly germinating sugarcane varieties, when setts were dipped in 120 ppm ethephon solution prior to planting. Increase in tiller population was also reported by Millhollon and Legendre (1995) from Louisiana when ethephon (250 ppm) was applied as a whole stalk treatment.

\subsection{Shoot height}

Shoot height varied significantly at all the growth stages due 
Table 1: No. of tillers ('000 ha-1), shoot height $(\mathrm{cm})$, No. of millable canes $\left(' 000 \mathrm{ha}^{-1}\right)$, cane yield $\left(\mathrm{t} \mathrm{ha}{ }^{-1}\right)$, green top yield $\left(\mathrm{t} \mathrm{ha}{ }^{-1}\right)$, trash yield $\left(\mathrm{t} \mathrm{ha}^{-1}\right)$, and economics as influenced by different treatments

\begin{tabular}{|c|c|c|c|c|c|c|c|c|c|c|c|c|c|c|}
\hline \multirow{3}{*}{$\begin{array}{l}\text { Treat- } \\
\text { ments }\end{array}$} & \multicolumn{4}{|c|}{ No. of tillers ('000 ha-1) } & \multicolumn{4}{|c|}{ Shoot height $(\mathrm{cm})$} & \multicolumn{4}{|c|}{ At harvest } & \multirow{3}{*}{$\begin{array}{c}\text { Net } \\
\text { return } \\
\left(₹ h^{-1}\right)\end{array}$} & \multirow{3}{*}{$\begin{array}{l}\mathrm{B}: \mathrm{C} \\
\text { ratio }\end{array}$} \\
\hline & 90 & 120 & 150 & 180 & 90 & 120 & 150 & 180 & $\mathrm{MC}$ & $\mathrm{CY}$ & GTY (t & TY & & \\
\hline & DAP & DAP & DAP & DAP & DAP & DAP & DAP & DAP & & (1 & & $(\mathrm{t})$ & & \\
\hline $\mathrm{T}_{1}$ & 66 & 18.49 & 128.10 & 118.88 & 166 & 18 & 2 & 273 & 3.33 & 67.95 & 18.14 & 5.92 & 134873 & 1.14 \\
\hline$T_{2}$ & 105.92 & 41.44 & 151.66 & 136.66 & 185 & 206 & 280 & 308 & 82.21 & 87.10 & 20.36 & 6.66 & 190535 & 2.42 \\
\hline $\mathrm{T}_{3}$ & 105.73 & 137.77 & 146.99 & 131.99 & 201 & 223 & 30 & 314 & 79.25 & 84.07 & 18.70 & 6.29 & 4 & 2.00 \\
\hline $\mathrm{T}_{4}$ & 114.99 & 148.10 & 159.99 & 147.22 & 223 & 238 & 313 & 332 & 90.73 & 104.06 & 22.40 & 7.03 & 224548 & 2.37 \\
\hline $\mathrm{T}_{5}$ & 84.62 & 120.55 & 131.44 & 121.66 & 163 & 180 & 290 & 303 & 78.32 & 71.10 & 19.25 & 6.47 & 134566 & 1.53 \\
\hline $\mathrm{T}_{6}$ & 107.38 & 14 & 152.38 & 13 & 186 & 206 & 2 & 3 & 7 & 89.43 & 5 & 7.95 & 53 & 2.09 \\
\hline$T_{7}$ & 2 & 13 & .05 & 13 & 183 & 198 & 286 & 3 & 82 & 85 & 9 & 6 & & 1.86 \\
\hline $\mathrm{T}_{8}$ & 1 & & 3 & 1 & 21 & 23 & 323 & 3 & 92.77 & 114 & 23.51 & 8.14 & & 32 \\
\hline $\mathrm{T}_{9}$ & 102.38 & 132.77 & 140.72 & 131.43 & 175 & 190 & 266 & 293 & 79.99 & 74.99 & 18.32 & 6.84 & 146112 & 1.69 \\
\hline $\mathrm{T}_{10}$ & 109.05 & 139.44 & 149.77 & 135.55 & 178 & 190 & 270 & 298 & 81.10 & 81.29 & 19.06 & 7.03 & 155807 & 1.63 \\
\hline SEm \pm & 2.76 & 2.8 & 2.16 & 1.82 & 5.69 & 5.29 & 4.98 & 5.38 & 1.14 & 2.04 & 0.41 & 0.23 & 5763 & 0.06 \\
\hline$C D^{*}$ & 8.2 & 8.34 & 6.41 & 5.43 & 16.92 & 15.72 & 14.79 & 15.98 & 3.40 & 6.06 & 1.21 & 0.70 & 17122 & 0.19 \\
\hline
\end{tabular}

NMC: No. of millable canes ('000 ha-1); CY: Cane yield; GTY: Green top yield; TY: Trash yield; CD*: CD ( $p=0.05)$

to different treatments. Soaking of setts with etehephon was found to be effective in improving shoot height, however the response was both time and concentration dependent. At both the concentration (i.e. 50 and $100 \mathrm{ppm}$ ) of ethephon, overnight soaking of setts with ethephon was found to be more efficient as compared to 6 hour soaking.

It was very interesting to observe that the increase in shoot height due to application of gibberellic acid at 90 DAP was initially slow but the subsequent application of gibberellic acid at 120 DAP resulted in much higher increase in shoot height and the response of $\mathrm{GA}_{3}$ application again decreased when sprayed at 150 DAP.

Final shoot height was taken at 180 days after planting. The highest shoot height was recorded in the treatment in which setts were soaked overnight in $100 \mathrm{ppm}$ ethephon followed by foliar application of Gibberellic acid (35 ppm) at 90, 120 and 150 DAP. It might be due to combined effect of overnight sett soaking with $100 \mathrm{ppm}$ ethephon and foliar application of Gibberellic acid.

Improvement in stalk height due to foliar appliacation of gibberellic acid was also reported by El-lattief and Bekheet (2012).

\subsection{No. of millable canes}

Data pertaining to number of millable canes revealed that number of millable cane (NMC) were recovered significantly higher in the treatment $T_{8}$ (overnight soaking with $100 \mathrm{ppm}$ ethephon followed by GA ${ }_{3}$ application @ 35 ppm applied at 90, 120 and 150 DAP) over rest of the treatments except $T_{4}$ (overnight soaking of setts with 100 ppm ethephon without
$\mathrm{GA}_{3} @ 35$ ppm at 90, 120 and 150 DAP). The higher number of millable cane production might be attributed to higher number of tiller production in the corresponding treatments. All the treatments could significantly improve no. of millable canes over control. El-Lattief and Bekheet (2012) from Egypt reported that foliar spray of $\mathrm{GA}_{3}$ in sugarcane improved the stalk population ha-1.

\subsection{Cane yield}

Highest cane yield (114.06 t ha-1) was obtained from the treatment of overnight soaking of cane setts in $100 \mathrm{ppm}$ ethephon followed by three spraying of $\mathrm{GA}_{3} @ 35$ ppm at 90,120 and 150 days after planting. Corresponding cane yield in this treatment $\left(\mathrm{T}_{8}\right)$ was $67.85 \%$ higher than conventional method (no treatment). The highest cane yield in this treatment was due to higher no. of millable canes as well as high cane weight. Cane yield was increased in all the treatments over conventional, though the response was different in different treatments. Even overnight soaking of setts in water before planting produced $28.18 \%$ higher cane yield over conventional. Sett treatment with ethephon improved germination and hence plant stand in all the treatments though the response was different for different duration ( 6 hour or overnight) as well as concentration (50 or $100 \mathrm{ppm}$ ) of sett soaking with ethephon. Ethephon soaking also improved tiller formation as has been elaborated earlier. Hence it ensured an optimum tiller count and ultimately higher no. of millable cane formation. Further application of Gibberellic acid again improved the growth which further improved cane growth and hence yield. Alexander (1968) also reported increase in yield of sugarcane due to foliar 
application of gibberellic acid.

\subsection{Green top and trash yield}

The highest green top yield was recorded in the treatment $\mathrm{T}_{8}$ (overnight soaking of setts in $100 \mathrm{ppm}$ ethephon followed by $\mathrm{GA}_{3}$ spray @ 35 ppm at 90, 120 and 150 DAP which was significantly higher over rest of the treatments except $\mathrm{T}_{4}$ (overnight soaking of setts in 100 ppm ethephon). The highest green top yield was due to high leaf area index observed in this treatment. Highest dry leafs (trash) yield were recorded in the treatment $\mathrm{T}_{8}$, which was significantly higher over rest of the treatments except $\mathrm{T}_{6}$ (overnight soaking of setts in water followed by $\mathrm{GA}_{3}$ spraying at 90, 120 and $\left.150 \mathrm{DAP}\right)$.

\subsection{Economics}

Net return and benefit cost ratio was calculated as the indices of acceptability or economic feasibility of the new technology. In the present study maximum net return was obtained in $\mathrm{T}_{8}$ which was $₹ 243762$ with a B:C ratio of 2.32 . It is noteworthy that water soaking treatment showed highest $\mathrm{B}: \mathrm{C}$ ratio (2.42) as it improved yield without involving much additional input cost, however the net return in this treatment was significantly lower as compared to $\mathrm{T}_{8}$. In terms of $\mathrm{B}: \mathrm{C}$ ratio, all the treatments performed well economically except $T_{5}$, $\mathrm{T}_{9}$ and $\mathrm{T}_{10}$ as the additional input cost over control could not bring a notable increase in net return.

\section{Conclusion}

Application of plant growth regulators was found to have a role in tiller dynamics of sugarcane. Sett soaking with 100 ppm ethephon followed by foliar application of Gibberellic acid@ @ 35 ppm at 90, 120 and 150 ppm was found to be the best proposition for improving tiller count, no. of millable cane production and cane yield.

\section{Reference}

Anonymous, 2011. Vision 2030. Indian institute of sugarcane research, Lucknow-226002, Uttar Pradesh, India, 1-4.

Anonymous, 2013. Status paper on sugarcane. Directorate of sugarcane development, Ministry of agriculture,
Department of agriculture and cooperation, Lucknow, Uttar Pradesh, India, 2-3.

Alexander, A.G., 1968. Interrelationship of GA and nitrate in sugar production and enzyme activity of sugarcane. Journal of Agriculture of the University of Puerto Rico 52(1), 19-28.

Diaz, J.C., Gonzalez-Tellez, F., Perez, L., Guevara, H., Zuaznaber, R., 1995. Effects of seedcane treatment with ethephon on germination, population and yields of sugarcane. International Sugar Journal 44, 69-72.

El-Lattief, E.A.A., Bekheet, M.A., 2012. Quantitative and qualitative attributes of three sugarcane varieties as influenced by foliar spray of some growth regulators under upper Egypt conditions. Sugar Technology 14(4), 345-350.

Gomez, K.A., Gomez, A.A., 1984. Statistical procedure for agricultural research. John Wiley and Sons, New York. 20-27.

Jain, R., Solomon, S., Chandra, A., 2011. Some discernible Physio-biochemical changes associated with improved sprouting of sugarcane setts treated with Ethephon. Sugar Technology 13(2), 123-128.

Kapur, R., Duttamajumder, S.K., Rao, K.K., 2011. A breeder's perspective on the tiller dynamics in sugarcane. Current Science 100(2), 183-189.

Li, Y., Solomon, S., 2003. Ethephon: a versatile growth regulator for sugarcane industry. Sugar Technology 5(4), 213-223.

Millhollon, R.W., Legendre, B.L., 1995. Influence of ethephon on plant population and yield of sugarcane (Saccharum spp. hybrids). Quarterly Plant Growth Regulator Society of America 23, 17-30.

Shrivastava, A.K., Misra, S.R., 1996. Tillering in sugarcane. Technical Bulletin No 35, Indian Institute of Sugarcane Research, Lucknow, 10.

Vasantha, S., Shekinah, D.E., Gupta, C., Rakkiyappan, P., 2012. Tiller production, regulation and senescence in sugarcane (Saccharum species hybrid) genotypes. Sugar Technology 14(2), 156-160. 